\title{
New palynological evidence for the age of the Beda Formation, Sirte Basin, Libya
}

\section{Arun Kumar}

\begin{abstract}
The Beda Formation represents the subsurface sequence of interbedded limestone with subordinate dolomites, which are major hydrocarbon reservoirs in the western Sirte Basin of Libya. Middle Paleocene (Montian) age has been assigned to this formation based on foraminifera, but the list of those age diagnostic foraminifera could not be found in the published literature, thus the age of this formation is questionable. Thick Paleocene-Early to Middle Eocene limestones and calcareous claystones also occur in this basin. Palynological study of 32 core samples of the Beda Formation from four different wells was carried out; but only four samples of Core \# 1 (6854'-6884') in the Well \# X43 yielded low diversity yet workable assemblages of palynomorphs. The pollen grains and spores indicate a Paleogene age. However, the dinoflagellate cyst assemblages provide several stratigraphically significant forms that indicate an EarlyMiddle Eocene age.

The results of the present study suggest that either the studied samples do not belong to the Beda Formation or the age of the Beda Formation ranges from Middle Palaeocene to Early-Middle Eocene. An extensive study of large numbers of core samples from several well sections is suggested to generate new micropaleontological and palynological data that could conclusively define age of the Beda Formation.
\end{abstract}

Arun Kumar. Department of Earth Sciences, Carleton University, 1125 Colonel By Drive, Ottawa, ON K1S 5B6, Canada. arunkumarlko@hotmail.com

Keywords: Beda Formation; Sirte Basin Libya; Dinoflagellate cysts; Palaeocene-Eocene Palynology; Foraminifera; Palynology

Submission: 28 January 2016 Acceptance: 3 October 2016

\section{INTRODUCTION}

Paleogene limestones and dolomites form several reservoir rocks in the Sirte Basin and are often difficult to correlate in the well sections exclusively based on radioactive and other logs. For ongoing hydrocarbon exploration in this basin definite time constraints for these reservoir rocks are needed. The Beda Formation represents the subsurface sequence of interbedded limestone with subordinate dolomites that are major hydrocarbon reservoirs in the western Sirte Basin of Libya. Barr and Weeger (1972) assigned Middle Paleocene (Montian) age to this formation based on foraminifera but the dinoflagellate cysts indicate a younger Early-Middle Eocene age instead. A search for 


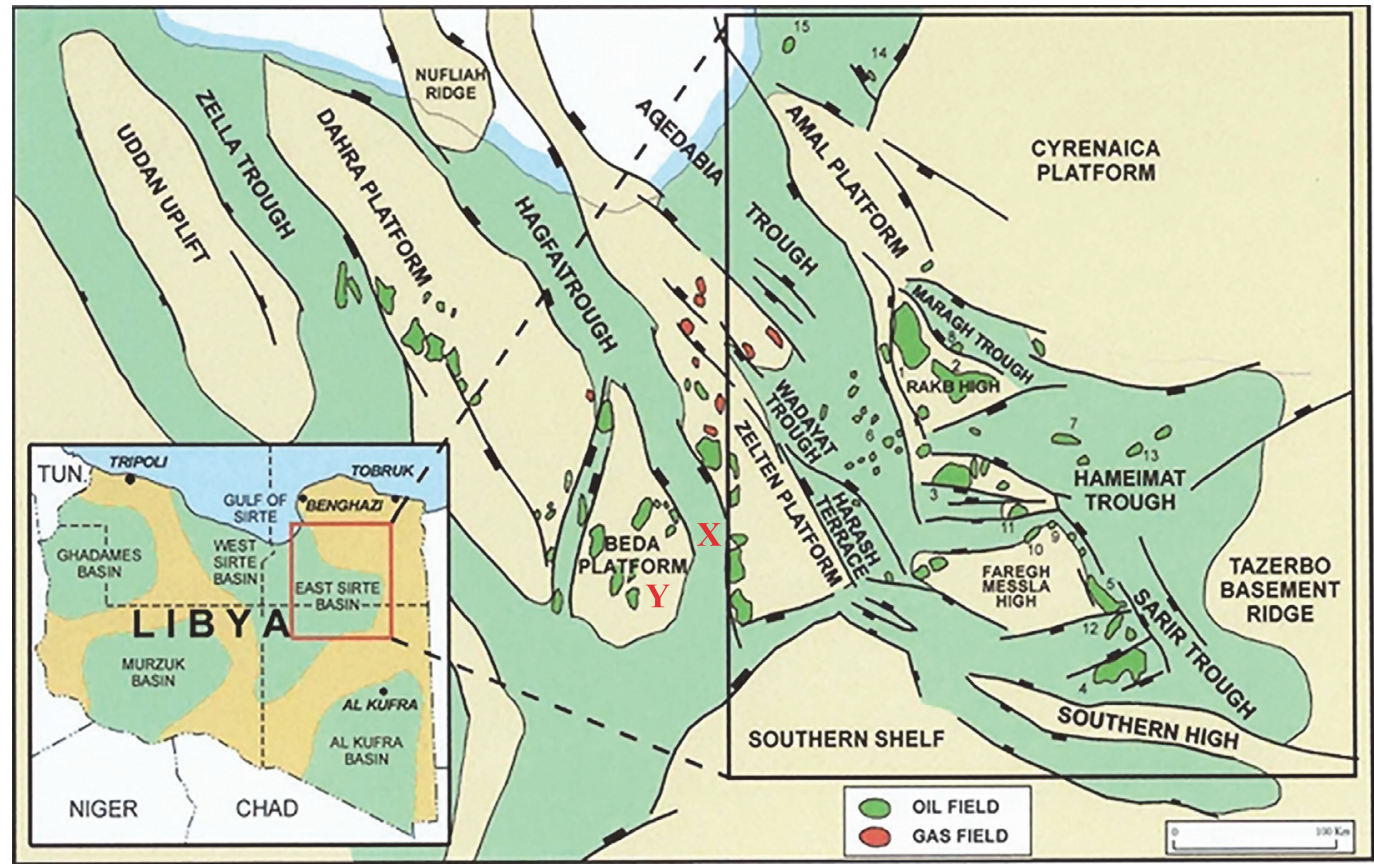

FIGURE 1. Structural elements of the Sirt Basin, Libya showing locations of major oil and gas fields. Location $X$ indicates wells $\mathrm{X} 13, \mathrm{X} 23$, and X43 in the Hagfa Trough and location $Y$ indicates well Y47 on the Beda Platform. (modified after Burwood et al. 2003, NARG website).

those age diagnostic Montian foraminifera could not be found in the published literature, thus it is not possible to reevaluate the assemblage; therefore the age of this formation is open to question. Thick Paleocene-Early to Middle Eocene limestones associated with calcareous claystones also occur in this basin that are not part of the Beda Formation. A clear definition and demarcation of the Beda Formation is required for correlating well sections. The objective of this study is to assign an age to the Beda Formation based on palynomorphs thus helping in identifying this formation in the well sections of the Sirte Basin.

\section{THE SIRTE BASIN}

The Sirte (also spelled as Sirt) Basin (Figure 1 ) is located in the north-central part of Libya and covers an area of about $600,000 \mathrm{~km}^{2}$ and contains $7,500 \mathrm{~m}$ thick sediments (Hallett, 2002). It is a Paleozoic Basin characterized by a series of platforms and deep troughs containing several large and small oil and gas fields. The sedimentary fill is predominantly of Mesozoic and Cenozoic age (Hallett, 2002). The geological history of this basin has been discussed by Wennekers et al. (1996) and the three volumes of the "Geology of the Sirt Basin" edited by Salem et al. (1996a, 1996b, 1996c) pro- vide detailed information about diverse aspects of petroleum geology of this basin.

According to an earlier estimate this basin ranked $13^{\text {th }}$ largest petroleum province in the world and contained 43.1 billion barrels of oil equivalent (Ahlbrandt, 2001). Upper Cretaceous Sirte Shale is the main source rock. Reservoir rocks range in age from fractured Precambrian basement, clastic reservoirs in the Cambrian-Ordovician sandstones, and Lower Cretaceous sandstone to Paleocene and Eocene carbonates commonly in the form of bioherms. These reservoirs are charged by vertically migrating hydrocarbons along horst block faults from Upper Cretaceous source rocks that occupy structurally low positions in the grabens. Evaporites in the middle Eocene provide seal for the hydrocarbon system in this basin (Ahlbrandt, 2001).

\section{THE BEDA FORMATION}

The Beda Formation was proposed by Barr and Weegar (1972) for the subsurface sequence of interbedded limestone with subordinate dolomite and calcareous shale in the western Sirte Basin. Its type section is in the OASIS BBB 1-59 well between 5525-5950 feet, thus its thickness in the type section is 425 feet, but these authors (Barr and Weegar, 1972, p. 37) erroneously state, "The 
Beda Formation varies in thickness from a few feet to a maximum of over 800 feet. It has a thickness of 45 feet in its type section." I believe it is just a printing error; 45 feet should have been 425 feet. Beda Formation overlies Hagfa Shale Formation (Lower Paleocene) and underlies Dahra Formation (Paleocene), and Barr and Weegar (1972) state, "Foraminiferal faunas indicate a Middle Paleocene age, probably Montian." However, they do not provide any list of age diagnostic foraminifers that indicate a Montian age for this formation. In the southwestern part of the Sirte Basin this formation has been subdivided into an upper and lower member based mainly on the electric-log character. In the northwestern part of the basin this formation becomes shalier and is subdivided into a lower Thalith Member and an upper Rabia Shale Member.

Bezan et al. (1996) while discussing the Palaeocene sequence in the Sirte Basin says ( $p$. 97) "Frequent lithofacies changes have given rise to unresolved nomenclature and correlation problems." He further states (p. 101-103), "Montian section is well defined only along the western shelf where it is represented by the Beda Formation (Figs 6,7) which was formally introduced and divided into three carbonate members by Barr and Weegar (1972)." This is an erroneous statement, because Barr and Weegar (1972) subdivided the Beda Formation into two members and not three. Attempts to describe subsurface Paleocene stratigraphy of the Sirte Basin have resulted in several new names applicable only locally. There is nomenclatural difference with the Esso Standard Libya classification (1962) where Thalith and Lower Beda Members are grouped into the Meem Member, and Upper Beda is considered to be equivalent to the Ora Member.

A survey of the published papers on the Beda Formation was done to find out if there is any definite information available on the age of this formation. There are a few papers that deal with various aspects of the geology of the Beda Formation in the volumes on the Geology of the Sirte Basin (Salem et al., 1996a, 1996b, 1996c). Garea (1996) while discussing the depositional environment and diagenesis of the Beda Reservoir in southwest Sirte Basin considers Beda Formation (Lower and Upper Members) as Montian that overlies Danian Hagfa Shale Formation and underlies Landenian Khalifa (Dahra) Shale Formation. Bezan et al. (1996) divided the Beda Formation into three members, they are Thalith (argillceous limestone), Lower Beda (also known as Beda C; sleletal, oolitic, and algal calcarinitic limestone) and Upper Beda (restricted shelf deposit: limestones and shales) in ascending order. According to Sinha and Mriheel (1996) marine transgression during which Hagfa Formation was laid is time-transgressive covering Danian-Early Landenian stages; and thus should be accorded the status of a Group. They elevated Hagfa, Upper Satal, Thalith, Lower Beda, Upper Beda, and Zeltan to the formation level. However, they (Sinha and Mriheel, 1996) were uncertain in assigning ages to the newly proposed Thalith Formation (partly Early Montian); Lower Beda Formation (possibly Early Montian), and Upper Beda Formation (possibly Late Montian). Johnson and Nicoud (1996) put Beda Formation in the Middle Paleocene.

There are a few references on the foraminiferal studies covering the Paleocene section of the Sirte Basin (Berggren, 1969, 1974). Biostratigraphical studies by Tmalla $(1992,1996)$ and determination of facies changes by Lehmann (1964) across the Cretaceous-Tertiary boundary in the Sirte Basin includes some micropaleontological data on the Paleocene. There are several unpublished reports on the biostratigraphic studies of the well sections in the Sirte Basin by the Robertson Research, where they have defined Paleocene sections in several wells. There is an important report on the biostratigraphy of western Sirte Basin that describes stratigraphic distribution of foraminifers (Bronnimann, 1962). But, an integration of the Beda Formation with Paleocene (possibly Montian) foraminiferal biostratigraphic zones is not available in any report.

This paper reports the results of a palynological study of the core samples from the subsurface well sections of the Beda Formation. The studied wells are located in two different tectonic zones of the Sirte Basin. The wells X13, X23, and X43 are closely spaced, thus indicated only by location $X$ in the Hagfa Trough, and Y47 is located on the Beda Platform (Figure 1). Dinoflagellate cysts data is primarily used to provide the age constraint to the Beda Formation.

\section{MATERIALS AND METHODS}

Following 32 samples (Table 1) from four wells (Well \# X43, Well \# Y47, Well \# X13, and Well \# X23) were macerated using standard palynological maceration procedures, and two slides of each sample were prepared. Slides were studied under Zeiss Optical Microscope using transmitted light. Each slide was scanned under X400 magnification and palynomorphs were photographed at 
TABLE 1. List of samples studied from various cores belonging to wells $X 43, Y 47, X 13$, and $X 23$.

\begin{tabular}{|c|c|c|}
\hline DEPTH & LITHOLOGY & PALYNOMORPH YIELD \\
\hline \multicolumn{3}{|c|}{ Well \# X43: Core \# 1 Beda Formation (6854'-6884') } \\
\hline $6854^{\prime} 8 ”$ & Shale & Fair \\
\hline 6863' 0" & Mudstone & Good \\
\hline 6871'4" & Mudstone & Poor \\
\hline 6872' 2" & Mudstone & Good \\
\hline $6880^{\prime} 6 ”$ & Limestone & Barren \\
\hline \multicolumn{3}{|c|}{ Well \# Y47: Core \# 1 Beda Formation (5965'-5995') } \\
\hline 5965 '0" & Mudstone & Barren \\
\hline $59700^{\prime \prime}$ & Mudstone & Barren \\
\hline 5972 ' 6” & Argillaceous wackestone & Barren \\
\hline 5991'4" & Grainstone with rootlet & Barren \\
\hline \multicolumn{3}{|c|}{ Well \# Y47: Core \# 2 Beda Formation (5995'-6025') } \\
\hline $6004^{\prime} 0 "$ & Grainstone & Barren \\
\hline $60177^{\prime \prime}$ & Grainstone & Barren \\
\hline 6022 '" & Grainstone & Barren \\
\hline \multicolumn{3}{|c|}{ Well \# X13: Core \# 1 Beda Formation (6885'-6929') } \\
\hline 6886 & Claystone (grey-brown) & Barren \\
\hline 6895 & Claystone (grey-brown) & Barren \\
\hline 6897 & Claystone (grey-brown) & Barren \\
\hline 6904 & Grey Shale & Barren \\
\hline 6905 & Grey Shale & Barren \\
\hline 6923 & Claystone (grey-brown) & Barren \\
\hline 6928 & Claystone (grey-brown) & Barren \\
\hline \multicolumn{3}{|c|}{ Well \# X23: Core \# 2 Beda Formation (7151'-7197') } \\
\hline $7152^{\prime}$ & Claystone & Barren \\
\hline 7157 & Claystone & Barren \\
\hline $7163^{\prime}$ & Claystone & Barren \\
\hline $7165^{\prime}$ & Claystone & Barren \\
\hline 7169 & Claystone & Barren \\
\hline $7174^{\prime}$ & Claystone & Barren \\
\hline $7177^{\prime}$ & Claystone & Barren \\
\hline 7183' & Claystone & Barren \\
\hline $7186^{\prime}$ & Claystone & Barren \\
\hline $7189^{\prime}$ & Claystone & Barren \\
\hline 7193' & Claystone & Barren \\
\hline 7194' & Claystone & Barren \\
\hline $7196 '$ & Claystone & Barren \\
\hline
\end{tabular}

both $\mathrm{X} 400$ and $\mathrm{X} 1000$ (oil immersion) using Jenoptic Camera System and ProgRes C5 software.

\section{RESULTS}

As can be seen above most of the 32 samples studied from four wells (Well \# X43, Well \# Y47, Well \# X13, and Well \# X23) are barren. The rea- son for so many barren samples is because most of them are limestones, dolomites, calcareous, and oxidized claystones, which usually (though not always) are barren of palynomorphs. It is well known that oxidation and the process of dolomitization destroys palynomorphs. 
Out of five samples from Core 1(6854'-6884') of the well $X 43$, four yielded low diversity yet workable assemblage of palynomorphs. Two samples contain good, well preserved and fairly diverse palynomorph assemblages of predominantly dinoflagellate cysts (Figures 2, 3) and angiospermous pollen grains (Figure 4). Table 2 lists all the palynomorphs recovered from these samples. Few specimens of acritarchs, fungal spores and foraminiferal remains were also observed (Figures 3, 4).

\section{DISCUSSION}

Conclusions regarding age are based only on the four productive samples of Core \# 1 of the Beda Formation (6854'-6884') in well \# X43. Table 3 shows the distribution of stratigraphically significant palynomorphs in these samples.

\section{Age of the Beda Formation in the Well \# X43:}

The dinoflagellate cyst assemblages of the Beda Formation samples are mainly cosmopolitan; are known from North Africa, Europe, India, and North America. They have several stratigraphically significant and age diagnostic forms. Their stratigraphic ranges are compared from three important works on the Tertiary dinoflagellate cysts (Williams and Bujak, 1985, Powell, 1992, Williams et al., 1993).

Dinoflagellate cysts. The following are stratigraphically significant and age diagnostic dinoflagellate cysts from the Beda Formation.

\section{Adnatosphaeridium multispinosum}

Williams and Bujak, 1985: Early-Middle Eocene Powell, 1992: Base at Early Eocene (Ypresian) Williams et al., 1993: Early Eocene (Ypresian) Middle Eocene (Bartonian)

\section{Apteodinium australiense}

Williams and Bujak, 1985: Early Eocene - Middle Miocene

Williams et al., 1993: Middle Eocene (Lutetian) Middle Miocene (Serravalian)

\section{Batiacasphaera compta}

Williams and Bujak, 1985: Middle-Late Eocene Williams et al., 1993: Middle Eocene (Bartonian) - Late Eocene (Priabonian)

\section{Fibrocysta cf. bipolaris}

Williams and Bujak, 1985: Paleocene-Early Eocene

\section{Homotryblium floripes}

Williams and Bujak, 1985: Middle Eocene - Middle Miocene
Powell, 1992: Base at Middle Eocene (Bartonian)

Polysphaeridium subtile
Williams and Bujak, 1985: Early - Middle Eocene

Tityrosphaeridium cantharellus

Williams and Bujak, 1985: Middle Eocene Early Miocene

Powell, 1992: Base is at Middle Eocene

Williams et al., 1993: Middle Eocene (Lutetian) Early Miocene (Aquitanian)

Stratigraphic ranges of the significant dinoflagellate cysts indicate an Early-Middle Eocene age for the studied samples of the Beda Formation.

Some age diagnostic forms like Adnatosphaeridium multispinosum, Apteodinium australiense, Batiacasphaera compta, Cordosphaeridium cantharellus, Fibrocysta cf. bipolaris, Homotryblium floripes, and Polysphaeridium subtile co-occur in the Middle -Late Eocene well sections of the Nile Delta of Egypt (El-Beiley, 1990), Nigeria (Jan du Chene and Adedrian, 1985) and Salt Range, Pakistan (Edwards, 2007). On the basis of palynological data from several wells from northeast Libya, Stead (2007) provided age ranges for the following dinoflagellate cyst species that occur in the Beda Formation; they are Adnatosphaeridium multispinosum (Subzone - LPT12a: Middle to Early Eocene), Cordosphaeridium cantharellus (Tityrosphaeridium cantharellus) (Middle Eocene (Lutetian) - Early Miocene (Burdigalian), Homotryblium floripes (Middle Eocene (Lutetian) Early Miocene (Burdigalian), Polysphaeridium subtile (Early Eocene (Ypresian) - Eerly Pliocene (Zanclian). Palaeocene-Eocene Thermal Maxima (PETM) event occurs at the Palaeocene-Eocene boundary in the marginal marine environments is known to be marked by the Apectodinium acme in the Tethyan realm (Crouch et al., 2003), but Apectodinium was not observed in the present study. On the basis of above observations it is suggested that the present dinoflagellate cyst assemblage represents an Early-Middle Eocene (late Ypresian Lutetian) age for the studied samples of the Beda Formation.

Pollen grains. The pollen grains and spores recovered from the Beda Formation are commonly known to occur in the Paleogene sediments from different parts of the world (Kumar and Takahashi, 1991; Kumar, 1994). A comprehensive catalogue of Tertiary fossil spores and pollen from India (Saxena and Trivedi, 2006; Saxena and Tripathi, 2012) provides stratigraphic occurrences of all the known fossil pollen and spores from India. Several ele- 

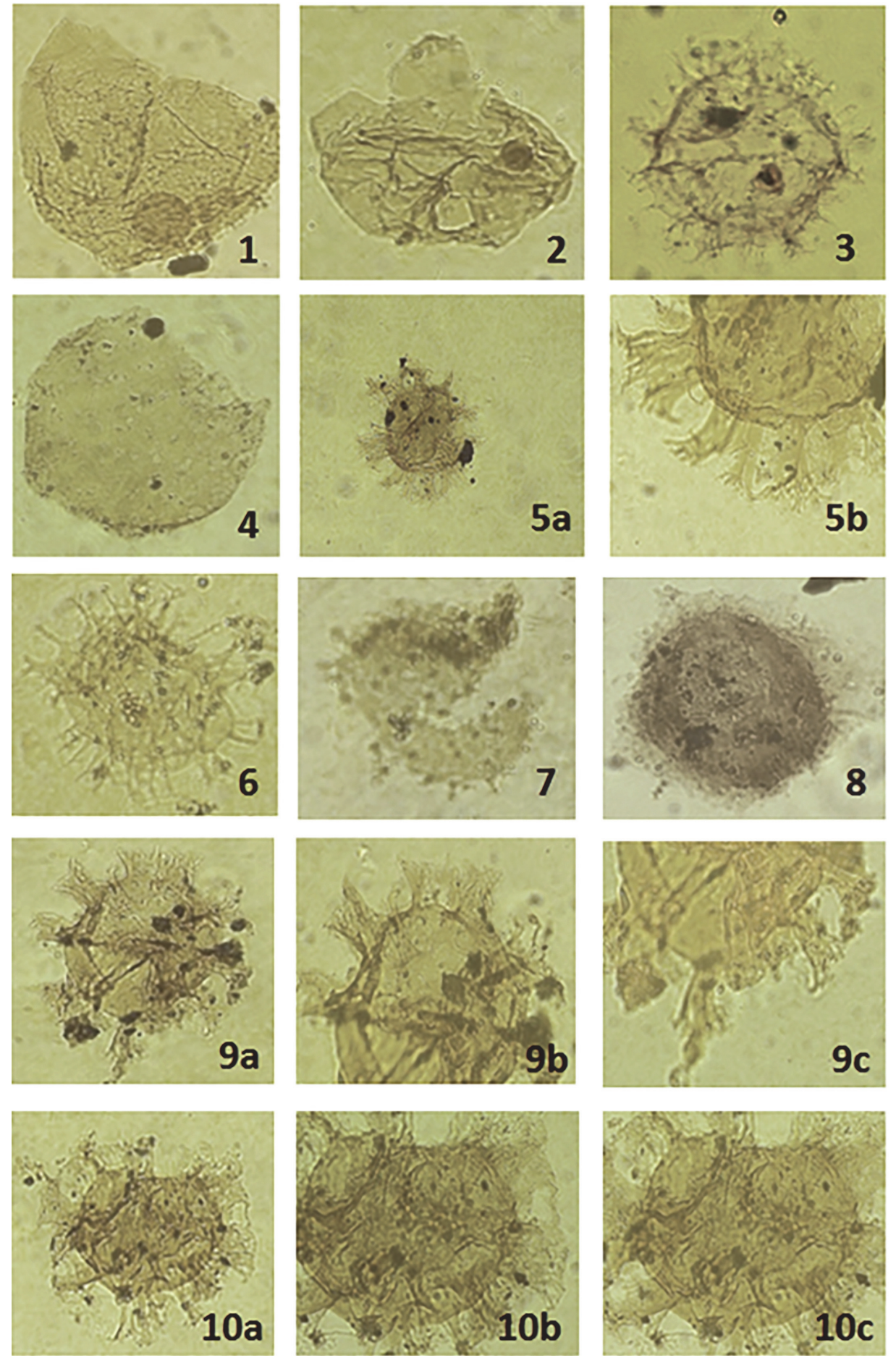

FIGURE 2. Dinoflagellate cysts. 2.1. cf. Cyclonephelium sp. (6854' 8", slide 1: 97.2 x 23). Size: $41 \times 31 \mu \mathrm{m}$. 2.2. Canningia sp. (6854' 8", slide 2: 95 x 37.7). Size: $28 \times 17 \mu \mathrm{m}$. 2.3. Spiniferites ramosus group (6854' 8", slide 2: 95 x 37.7). Cyst diameter $19 \mu \mathrm{m}$; and process length 3-4.5 $\mu \mathrm{m}$. 2.4. Batiacasphaera compta (6871' 4", Slide 1: 91.5x33.4). Cyst diameter $32 \times 27 \mu \mathrm{m}$. 2.5. Homotryblium floripes (6871, slide 1: 95.9x32.1) Cyst diameter $38 \mu \mathrm{m}$; and process length 12-15 $\mu \mathrm{m}$. 2.6. Spiniferites ramosus group (6863, slide 2: $97.8 \times 33$ ). Cyst diameter $27 \mu \mathrm{m}$; and process length $5 \mu \mathrm{m}$. 2.7. Polysphaeridium subtile (6863, slide 2: $104.8 \times 38$ ). Cyst diameter $13 \mu \mathrm{m}$; process length 2-3 $\mu \mathrm{m}$. 2.8. Operculodinium centrocarpum (6863, slide 1: $100 \times 38.8$ ). Cyst diameter $28 \times 24 \mu \mathrm{m}$; and process length $4-5 \mu \mathrm{m}$. 2.9. Fibrocysta

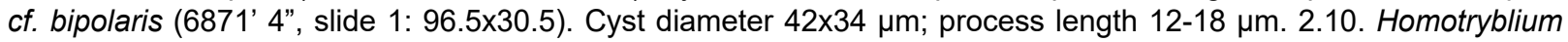

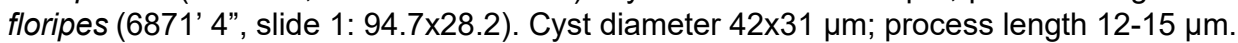



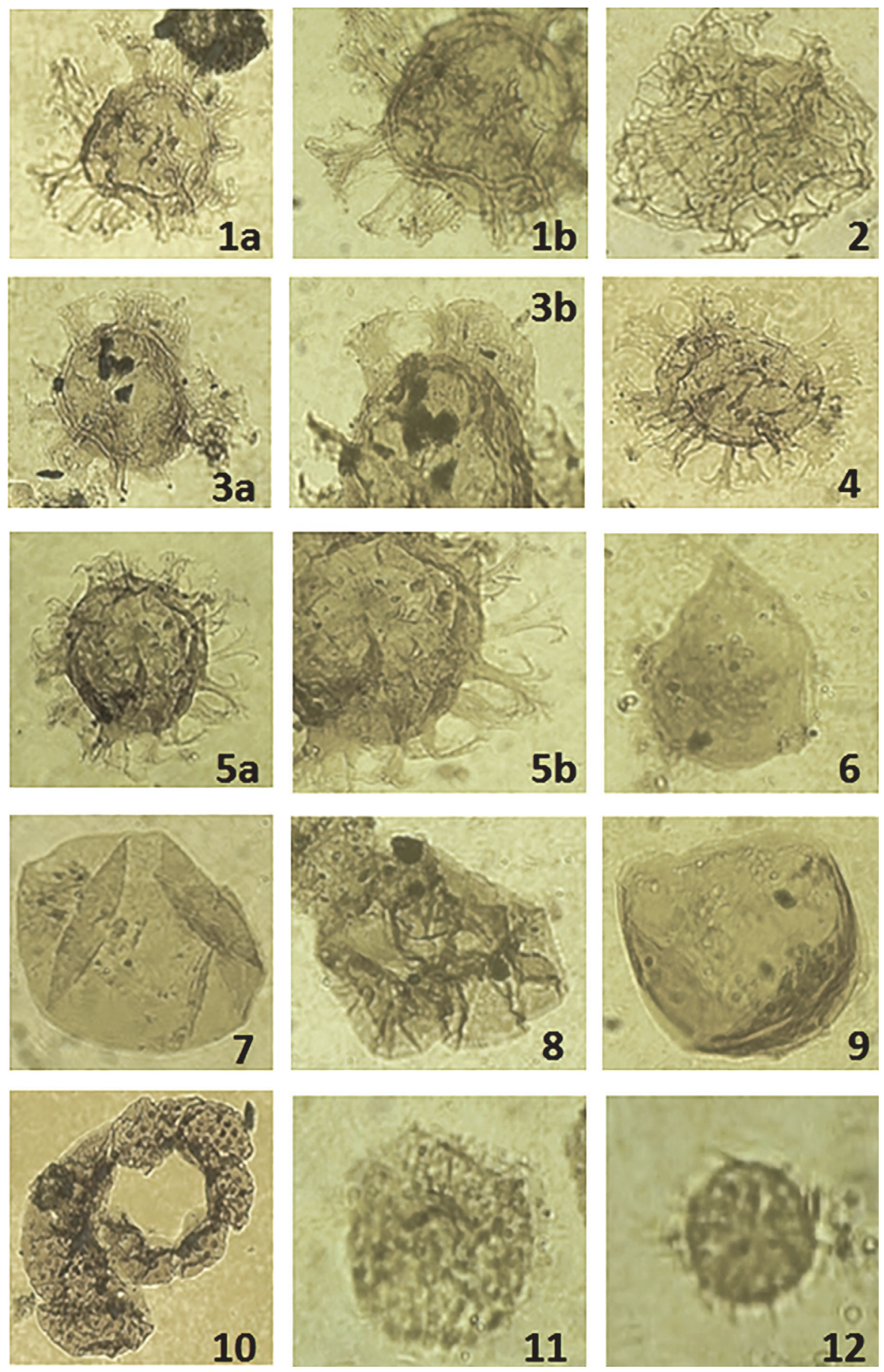

FIGURE 3. Dinoflagellate cysts, acritarchs and foraminiferal remains. 3.1. Homotryblium floripes (6871' 4", slide 1: 96.5x30.5). Cyst diameter $32 \mu \mathrm{m}$; process length 11-14 $\mu \mathrm{m}$. 3.2. Adnatosphaeridium multispinosum (6872' 2", slide 1: 101.9x36). Cyst diameter $22 \mu \mathrm{m}$; process length 8-10 $\mu \mathrm{m}$. 3.3. Homotryblium floripes (6871' 4", slide 2: 103.5x35.7). Cyst diameter $40 \mu \mathrm{m}$; process length 11-13 $\mu \mathrm{m}$. 3.4. Homotryblium floripes (6872' 2", slide 1: 96.8x38). Cyst diameter $42 \mu \mathrm{m}$; process length 13-15 $\mu \mathrm{m}$. 3.5. Tityrosphaeridium cantharellus (6872' 2", slide 1: 97.8x28.7). Cyst diameter 36

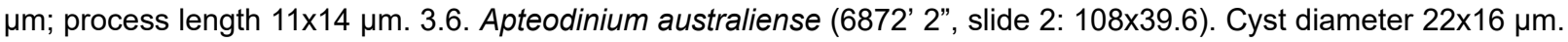
3.7. Leiosphaeridia sp. (6872' 2", slide 1: 98.2x24.6). Cyst diameter 21x14 um. 3.8. cf. Pterospermella sp. (6872' 2",

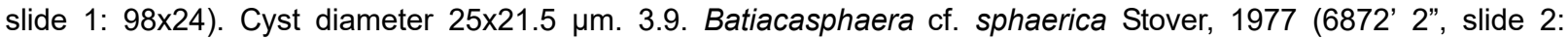

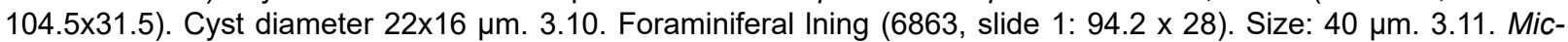
rhystridium sp. (6863, slide 2: $103.4 \times 30$ ). Cyst diameter $15 \mu \mathrm{m}$; and process length 3-4 $\mu \mathrm{m}$. 3.12. Micrhystridium sp. (6863, Slide 2: $103.2 \times 32.3$ ). diam. $7 \mu \mathrm{m}$; proc. $2-3 \mu \mathrm{m}$. 

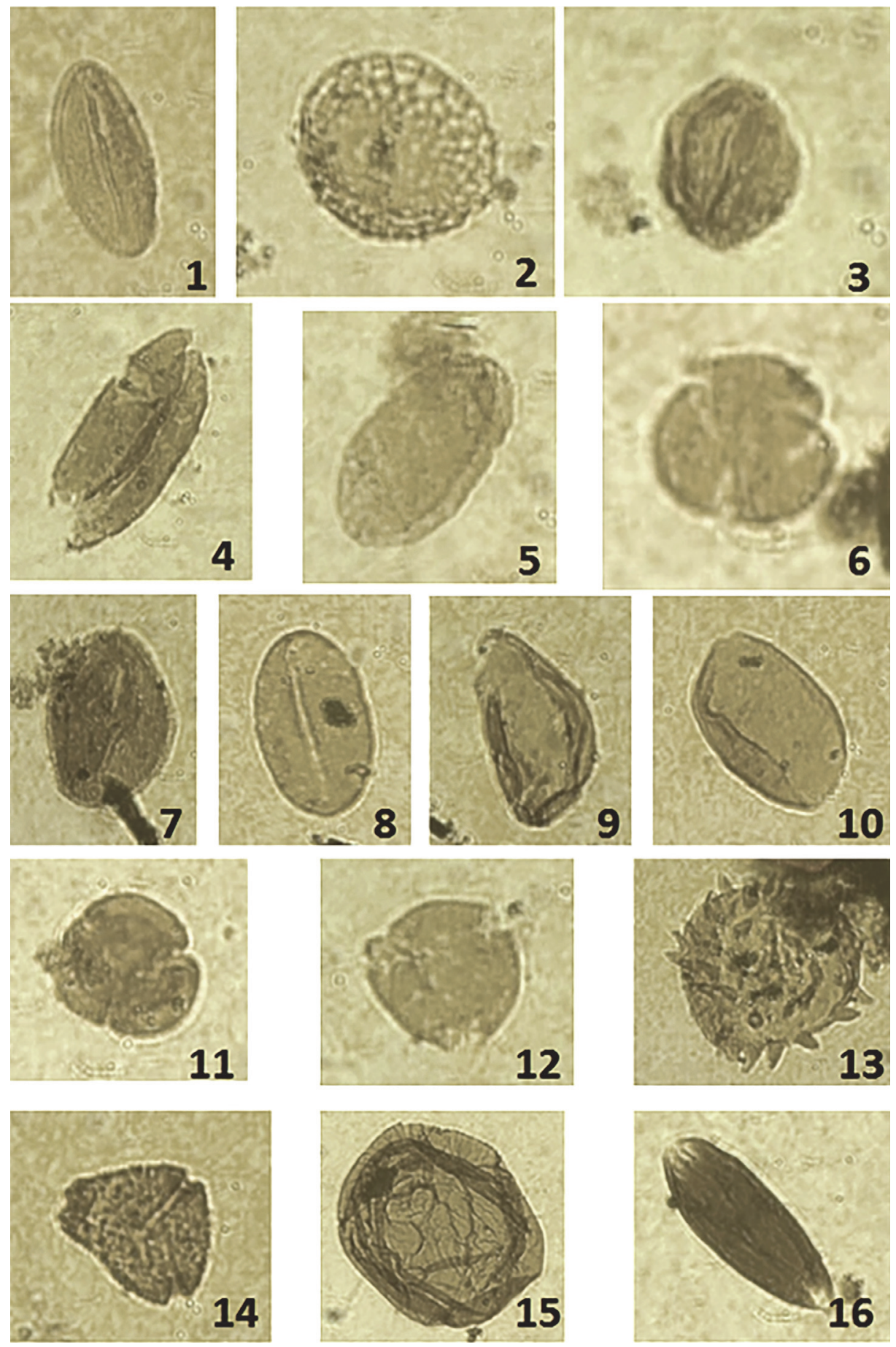

FIGURE 4. Pollen grains and fungal remains. 4.1. Arecipites indicus (6854' 8", Slide 2: $95 \times 33.5$ ). Size: 14 x $6 \mu$ m. 4.2. Proxapertites cursus (6863', Slide 1: 98.4 x 32.4). Size: 14 m. 4.3. Retitricolpites sp. (6863', Slide 1: $101 \times 27$ ). Size: $8 \mu \mathrm{m}$. 4.4. Palmaepollenites sp. (6863', Slide 1: 107.4 x 35.8). Size: $23 \times 11 \mu \mathrm{m}$. 4.5. Proxapertites operculatus (6863', Slide 2: 105.2 x 39). Size: $15 \times 8 \mu \mathrm{m}$. 4.6. Tricolpites microreticulatus (6863', Slide 2: 105.5 x 34.5). Size: $8 \mu \mathrm{m}$. 4.7. Tricolporopollenites sp. (6863', Slide 2: 94x31.5). Size: 16x $12 \mu \mathrm{m}$. 4.8. Arecipites indicus (6863', Slide 2: 93.8x39.2). Size: 19x $11 \mu \mathrm{m}$. 4.9. Palmidites sp. (6863', Slide 2: 95.7x31.2). Size: 16x $8 \mu \mathrm{m} .4 .10$. Palmidites sp. (6863', Slide 2: 92x37.6). Size: 18x12 $\mu \mathrm{m}$. 4.11. Retibrevitricolpites sp. (6863', Slide 2: 92.4x25). Size: $10 \mu \mathrm{m} .4 .12$. Brevitricolpites sp. (6863', Slide 2: 104.4x33.5). Size: $10 \mu \mathrm{m} .4 .13$. Neocouperipollis sp. (6863', Slide 2: 91.5x29.6). Size: $16 \mu \mathrm{m}$. 4.14. Trisyncoloporopollenites sp. (6863', Slide 2: 90x23.2). Size: $12 \mu \mathrm{m}$. 4.15. Fungal spore (6863, slide 1: 99.6 x 33). Size: $30 \mu \mathrm{m} .4 .16$. Fungal remain (6863, slide 2: 105.6 x 30.3). Size: $23 \times 8 \mu \mathrm{m}$. 
TABLE 2. List of palynomorphs.

\section{A. Dinoflagellate Cysts}

1. Adnatosphaeridium multispinosum Williams and Downie, 1966

2. Apteodinium australiense (Deflandre and Cookson, 1955) Williams, 1978

3. Apteodinium sp.

4. Batiacasphaera compta Drugg, 1970

5. Batiacasphaera cf. sphaerica Stover, 1977

6. Batiacasphaera sp.

7. Canningia sp.

8. Cordosphaeridium sp.

9. Cyclonephelium sp.

10. Fibrocysta cf. bipolaris (Cookson and Eisenack, 1965) Stover and Evitt, 1978

11. Homotryblium floripes (Deflandre and Cookson, 1955) Stover, 1975

12. Hystrichosphaeropsis sp.

13. Operculodinium centrocarpum (Deflandre and Cookson, 1955) Matsuoka et al. 1997

14. Polysphaeridium subtile Davey and Williams, 1966

15. Spiniferites ramosus group (Ehrenberg, 1838) Mantell, 1854

16. Tityrosphaeridium cantharellus (Brosius, 1963) Sarjeant, 1981

\section{B. Acritarchs}

1. Leiosphaeridia spp.

2. Micrhystridium spp.

3. Pterospermella spp.

\section{Pollen Grains}

1. Arecipites indicus Venkatachala and Rawat, 1972

2. Brevitricolpites sp.

3. Neocouperipollis sp.

4. Palmaepollenites spp.

5. Palmidites $\mathrm{sp}$.

6. Proxapertites operculatus van der Hammen, 1956

7. Proxapertites cursus van Hoeken-Klinkenberg 1966

8. Retibrevitricolpites sp.

9. Retitricolpites sp.

10. Spinizonocolpites sp.

11. Tricolpites microreticulatus Venkatachala, 1973

12. Tricolpites spp.

13. Tricolporopollenites $\mathrm{sp}$.

14. Trisyncoloporopollenites sp.

\section{Spores}

1. Laevigatosporites sp.

2. Polypodiaceoisporites sp.

\section{E. Miscellaneous palynomorphs}

1. Foraminieral linings

2. Fungal spores

3. Fungal remains 
TABLE 3. Distribution of palynomorphs in four samples of core \#1 in well X43.

\begin{tabular}{|c|c|c|c|c|}
\hline \multirow{2}{*}{ Palynomorphs } & \multicolumn{4}{|c|}{ Core \# 1: Sample Depth (Feet) } \\
\hline & 6854' 8"' & 6863' 0"' & 6871'4"' & 6872' 2"' \\
\hline \multicolumn{5}{|l|}{ Dinoflagellate Cysts } \\
\hline Adnatosphaeridium multispinosum & & & & $\mathrm{P}$ \\
\hline Apteodinium australiense & & & & $\mathrm{P}$ \\
\hline Apteodinium sp. & & & & $\mathrm{P}$ \\
\hline Batiacasphaera compta & & & $\mathrm{P}$ & \\
\hline Batiacasphaera cf. sphaerica & $\mathrm{P}$ & & & \\
\hline Batiacasphaera spp. & $\mathrm{P}$ & $\mathrm{P}$ & & \\
\hline Canningia spp. & $\mathrm{P}$ & & & \\
\hline Tityrosphaeridium cantharellus & & & & $\mathrm{C}$ \\
\hline \multicolumn{5}{|l|}{ Cordosphaeridium spp. } \\
\hline Cyclonephelium spp. & $\mathrm{P}$ & & & \\
\hline Fibrocysta cf. bipolaris & & & $\mathrm{P}$ & \\
\hline Homotryblium floripes & & & $\mathrm{C}$ & $\mathrm{C}$ \\
\hline Hystrichosphaeropsis sp. & & & & $\mathrm{P}$ \\
\hline Operculodinium centrocarpum & & $\mathrm{P}$ & & \\
\hline Polysphaeridium subtile & & $P$ & & \\
\hline Spiniferites ramosus Group & $\mathrm{P}$ & $P$ & & $\mathrm{P}$ \\
\hline \multicolumn{5}{|l|}{ Acritarchs } \\
\hline Leiosphaeridia spp. & $\mathrm{P}$ & & & C \\
\hline Micrhystridium spp & & $P$ & & \\
\hline \multicolumn{5}{|l|}{ Pollen Grains } \\
\hline Arecipites indicus & $\mathrm{P}$ & $P$ & & \\
\hline Brevitricolpites sp & & $P$ & & \\
\hline Palmaepollenites spp. & & $P$ & & $\mathrm{P}$ \\
\hline Palmidites sp. & & $P$ & & \\
\hline Proxapertites operculatus & & $P$ & & \\
\hline Proxapertites sp. & & $P$ & & \\
\hline Spinizonocolpites sp. & & $\mathrm{P}$ & & \\
\hline Tricolpites microreticulatus & & $P$ & & \\
\hline Tricolpites spp. & & $P$ & & \\
\hline Tricolporopollenites sp. & & $P$ & & $\mathrm{P}$ \\
\hline \multicolumn{5}{|l|}{ Spores } \\
\hline Laevigatosporites sp. & $\mathrm{P}$ & $P$ & & \\
\hline Polypodiaceoisporites sp. & $\mathrm{P}$ & & & \\
\hline \multicolumn{5}{|l|}{ Miscellaneous palynomorphs } \\
\hline Foraminieral linings & & $P$ & & \\
\hline Fungal spores & & $P$ & & \\
\hline Fungal bodies & & $\mathrm{P}$ & & \\
\hline
\end{tabular}

ments of the pollen and spore assemblage the Beda Formation, for example, Arecipites indicus, Proxapertites operculatus, and Tricolpites microreticulatus co-occur in the Indian basins, and their time ranges indicate a Paleogene age. El Beialy
(1998) reported several taxa of angiosperm pollen from the Eocene of Oman that also occurs in the Beda Formation.

Thus the palynological results, especially based on the dinoflagellate cysts of the four sam- 
ples from the core \# 1 of well X43 of Sirte Basin indicate an Early-Middle Eocene age for the Beda Formation. Since this result does not conform with the currently accepted age of the Beda Formation, which is considered to be Middle Paleocene (Montian), it is important to discuss further reasons for this discordant result and find a scientific and logical solution to this problem. A literature survey of the published and unpublished micropaleontological data of the Paleocene of the Sirte Basin was carried out to understand why age of the Beda Formation was assigned to the Montian Stage.

Unpublished reports of the Robertson Group plc of the subsurface well sections (wells B1-12 and D1-32) from the Sirte Basin show presence of thick Paleocene-Early to Middle Eocene Limestones with subordinate calcareous claystones. The age of these rocks is primarily based on the poor microfaunal records of benthic as well as planktic foraminafers (Edwards et al., 1991a, 1991b).

There are few references on the foraminiferal studies covering Paleocene section of the Sirte Basin (Berggren, 1969, 1974; Tmalla, 1992, 1996; Lehmann, 1964). Additionally, there are several unpublished reports on the biostratigraphic studies of the wells in the Sirte Basin by Robertson Group Plc, where they have defined Paleocene sections in several wells (Edwards et al., 1991a, 1991b). However, I have not been able to find any information or reference on integration of the Beda Formation with Middle Paleocene (Montian) foraminiferal biostratigraphic zones.

There is a definite presence of the Paleocene marine sedimentary rocks in the Sirte Basin as demonstrated by both planktic foraminiferal evidence (Berggren, 1969) as well as benthic foraminiferal evidence (Berggren, 1974). Berggren (1969) presented a biostratigraphic subdivision of the Tertiary of northern and central part of the Sirte Basin in which he defined presence of the Montian stage. This information is not applicable to the age of the Beda Formation because this formation was proposed much later by Barr and Weegar in 1972 for a well section in the western part of the basin. Although this certainly does not mean that there is no Montian section in the western Sirte Basin, but the point of contention is that there is no data to prove the presence of Montian stage in the western Sirte Basin that could conclusively prove that Beda Formation is of Montian age. Berggren's later paper (Berggren, 1974) on the Paleocene biostratigraphy of the Sirte Basin does not mention presence of the Beda Formation; probably at the time of writing of this paper he was not aware of the publication of Barr and Weegar (1972). He (Berggren, 1974) divides Paleocene in the central part of the Sirte basin into Early (Danian) and Late (Thenetian) and there is no mention of Montian stage in this paper.

Since Barr and Weegar (1972) consider that Beda Formation overlies Hagfa Shale Formation (Lower Paleocene) and underlies Dahra Formation (Paleocene) thus it could be of Middle Paleocene (Montian) age (also according to them supported by the foraminiferal data), but according to Berggren (1974, figure 2) the age of Hagfa Shale Member (not formation as mentioned by Barr and Weeger, 1972) ranges from Late Cretaceous (Maestrichtian) to Late Paleocene (lower part of Thanetian). Thus the age the Beda Formation becomes latest Paleocene or Thanetian (not Middle Paleocene as suggested by Barr and Weeger, 1972) or possibly even Early-Middle Eocene. In the south and west of the Sirte Basin, Lower and Middle Paleocene are composed of three units: the lower shale, the middle limestone, and the upper shale. The lower shale passes laterally into coral-algal reef limestone locally on structural highs. A rich benthic and planktic foraminiferal fauna occurs in these shales and indicates deposition in depths ranging from $<30 \mathrm{~m}$ to somewhat $<200 \mathrm{~m}$ (Berggren, 1974). It is quite evident from the above discussion that there is no definite foraminiferal evidence to say that the Beda Formation belongs to the Middle Paleocene (Montian) age. Thus the age of the Beda Formation is still debatable.

Marine Eocene carbonate rocks are present in the subsurface throughout the Sirte Basin, forming major hydrocarbon reservoirs. In the Sirte Basin the dominant lithologies of the Eocene rocks are shallow-water carbonates, dolomites, and evaporites (Megerisi and Mamgain, 1980).

The palynological data from the four samples of the core \#1 of the well X43 indicates an EarlyMiddle Eocene age thus suggesting a discordant view that this core belongs to the Beda Formation of the Montian age. This result indicates that either the age of the Beda Formation ranges from Middle Paleocene (Montian) to Early-Middle Eocene or this core is not from the Beda Formation and instead belongs to the Eocene carbonate reservoirs of the Sirte Basin. An extensive study of large numbers of subsurface sections (cores from wells) is required to generate new micropaleontological (foraminiferal and other microfossil groups) and palynological data that will help conclusively to determine the age of the Beda Formation. 


\section{CONCLUSIONS}

1. The Beda Formation was proposed by Barr and Weegar (1972) for the subsurface sequence of interbedded limestone with subordinate dolomite and calcareous shale in the western Sirte Basin. They suggested, "Foraminiferal faunas indicate a Middle Paleocene age, probably Montian" but did not provide any list of foraminifers or any reference to the published literature that indicated a Middle Paleocene (Montian) age for this formation.

2. Unpublished reports of the Robertson Group plc of wells B1-12 and D1-32 from the Sirte Basin show presence of thick PaleoceneEarly to Middle Eocene Limestones with subordinate calcareous claystones. The age of these rocks is primarily based on the poor microfaunal records of benthic as well as planktic foraminfers (Edwards et al., 1991a, 1991b).

3. The published and unpublished literature on the foraminiferal studies covering Paleocene section of the Sirt Basin (Berggren, 1969, 1974; Tmalla, 1992, 1996; Lehmann, 1964; and Edwards et al., 1991a, 1991b) have shown no information on integration of the Beda Formation with Middle Paleocene (Montian) foraminiferal biostratigraphic zones.

4. There is definite presence of marine Paleocene in the Sirte Basin as demonstrated by both planktic foraminiferal evidence (Berggren, 1969) as well as benthic foraminiferal evidence (Berggren, 1974). However, this information is not applicable to the Beda Formation because this formation was proposed by Barr and Weegar in 1972 and was not referred in Berggren, 1974.

5. In the present study conclusions regarding age are based only on the four productive samples of Core \# 1 of the Beda Formation (6854'-6884') in the Well \# X43.

6. The dinoflagellate cyst assemblages have several stratigraphically significant forms; their stratigraphic ranges are compared among the four important publications on the Tertiary dinoflagellate cysts (Williams and Bujak, 1985; Powell, 1992; Williams et al., 1993, and Stead, 2007).

7. The pollen grains and spores recovered in this study are known to occur in the Paleogene sediments in different parts of the world (Kumar and Takahashi, 1999; Kumar, 1994).
8. A catalogue of Tertiary fossil spores and pollen from India (Saxena and Trivedi, 2006) provides stratigraphic co-occurrences of most of the Beda Formation pollen and spores in the Palaeogene sediments of India.

9. The palynological data in the present study indicates an Early-Middle Eocene age for the four productive samples in the Well \# X43. This suggests that either (1) these samples do not belong to the Beda Formation as defined by Barr and Weeger (1972) or (2) the age of the Beda Formation ranges from Middle Palaeocene to Early-Middle Eocene.

10. There is no definite foraminiferal evidence to say that the Beda Formation belongs to the Montian stage, thus its age is open to question.

11. An extensive study of large numbers of samples from well sections is required to generate new micropaleontological and palynological data that will help conclusively to define the age of the Beda Formation.

\section{ACKNOWLEDGEMENTS}

I express my sincere gratitude to Mr. A. Muftah (Superintendent) and Mr. M. Erhuma (Laboratory Coordinator) of the Geological Laboratories, Sirte Oil Company for providing support for this work. I also thank Sirte Oil Company for permission to publish this paper. I sincerely thank Mr. Nawaf Nasser of the Department of Earth Sciences, Carleton University for improving the quality of figures.

\section{REFERENCES}

Ahlbrandt, T.S. 2001. The Sirte Basin Province of LibyaSirte-Zelten; Total Petroleum System. United States Geological Survey Bulletin, 2202-F:1-29.

Barr, F.T. and Weegar, A. A.1972. Stratigraphic nomenclature of the Sirte Basin, Libya. The Petroleum Exploration Society of Libya, Tripoli, Libya.

Berggren, W.A. 1969. Biostraigraphy and planktonic foraminifera zonation of the Tertiary System of the Sirte Basin of Libya, p.104-120. In Bronnimann, P. and Renz, H. H. (eds.), Proceedings of 1st International Conference on Planktonic Microfossils. E.J. Brill, Leiden.

Berggren, W.A. 1974. Paleocene benthonic foraminferal biostratigraphy and paleoecology of Libya and Mali. Micropaleontology, 20:449-465.

Bezan, A.M. 1996. The Palaeocene Sequence in Sirt Basin, p. 97-118. In Salem, M.J., Mouzughi, A.J. and Hammuda, O.S. (eds.), The Geology of Sirt Basin 1, Tripoli, Libya. 
Bezan, A.M., Belhaj, F., and, Hammuda, K. 1996. The Beda Formation in Sirt Basin, p. 135-152. In Salem, M.J., A.S. El-Hawat, A.J. and Sbeta, A.M. (eds.), The Geology of Sirt Basin 2, Tripoli, Libya.

Bronnimann, P. 1962. Biostratigraphy of western Sirte Basin, Libya. Sirte Oil Company, Geological Report, Brega, Libya.

Brosius, M. 1963. Plankton aus dem nordhessischen Kasseler Meeressand (Oberoligozän). Zeitschrift der Deutschen geologischen Gesellschaft, 114:32-56.

Burwood, R., Redfern, J., and, Cope, M J. 2003. Geochemical evaluation of East Sirte Basin (Libya) petroleum systems and oil provenance. In Geological Society Special Publication (Vol. 207, pp. 203-240). Geological Society of London. Downloaded on August 4, 2014 from NARG website. www.narg.org.uk/research/basin/sirtekerogenjr

Cookson, I.C. and Eisenack, A. 1965. Microplankton from the Browns Creek Clays, southwestern Victoria. Proceedings of the Royal Society of Victoria, 79:119131.

Crouch, E.M., Brinkhuis, H., Visscher, H., Adatte, T., and, Bolle, M.P. 2003. Late Palaeocene-Early Eocene dinoflagellate cysts records from the Tethys: further observation on the global distribution of Apectodinium, p. 113-131. In Wing, S L., Gingerich, P.R., Schmitz, B., and Thomas, E. (eds.), Causes and consequences of globally warm climates in the Early Paleogene. Geological Society of America Special Paper 369.

Davey, R.J. and Williams, G.L. 1966. The genus Hystrichosphaeridium and its allies. Bulletin of the British Museum of Natural History (Geology), Supplement 353-106.

Deflandre, G. and Cookson, I. C. 1955. Fossil microplankton from Australian Late Mesozoic and Tertiary sediments. Australian Journal of Marine and Fresh Water Research, 6:242-313.

Drugg, W.S. 1970. Some new genera, species and combinations of phytoplankton from the Lower Tertiary of the Gulf Coast, USA. North America Paleontological Convention, Chicago, 1969, Proceedings G:809-843.

Edwards, L.E., 2007, Paleocene and Eocene dinocysts from the Salt Range, Punjab, northern Pakistan, p. C-C10. In Warwick, P.D. and Wardlaw, B.R. (eds.), Regional studies of the Potwar Plateau area, northern Pakistan: U.S. Geological Survey Bulletin 2078.

Edwards, P.G., Fawzy, A., Hughes, P.W., Jakeman, M.D., Jeremiah, J.M., Matthews, S. L., Swire, P.H., and Underwood, J. 1991 b. The lithology, biostratigraphy and paleoenvironments of the interval 18'-8343' in the D1-32 well, Sirte Basin, onshore Libya. Project No. Ib/15228, Report No. 4153/lb (Revised). The Robertson Group Plc.

Edwards, P.G., Hughes, P.W., Jakeman, M.D., Jeremiah, J.M., Marshall, P.R., Underwood, J., and Varol, O. 1991 a. The lithology, biostratigraphy and paleoenvironments of the interval 47'-11280' in the B1-12 well, Sirte Basin, onshore Libya. Project No. Ib/15225,
Report No. 4212/lb (Revised). The Robertson Group Plc.

Eherberg, C.G. 1837. Über die fossilien infusorien-Gattunge Xanthidium und Peridinium. Archiv Naturgeschichte, 3:273-278.

El-Beialy, S.Y. 1990. Tertiary dinoflagellate cysts from the Mit Ghamr-1 well, Nile Delta, Egypt. Review of Palaeobotany and Palynology, 63:259-267.

El Beialy, S.Y. 1998. Stratigraphic and palaeoenvironmental significance of Eocene palynomorphs from the Rusayl Shale Formation, Al Khawd, northern Oman. Review of Palaeobotany and Palynology, 102:249-258.

Garea, B.B. 1996. Environment of deposition and diagenesis of the Beda Reservoir in Block NC74F, SW Sirt Basin, Libya, p. 115-134. In M.J. Salem, M.J., ElHawat, A.S., and Sbeta, A.M. (eds.), The Geology of Sirt Basin, Tripoli, Libya.

Hallett, D. 2002. Petroleum Geology of Libya. Elsevier.

Jan du Chene, R.E. and Adediran, S.A. 1985. Late Palaeocene to early Eocene dinoflagellates from Nigeria. Cahiers de Micropaleontologie, 3:1-38.

Johnson, B.A. and Nicoud, D.A. 1996. Integrated exploration for Beda Formation reservoirs in the southern Zalla Trough (west Sirt basin, Libya), p. 211-221. In Salem, M. J., El-Hawat, A.S. and A.M. Sbeta (eds.), The Geology of Sirt Basin, 2, Tripoli, Libya.

Kumar, A. 1994. Palynology of the Tertiary sediments exposed along the Silchar-Haflong Road Section, southern Assam. Palaeontographica Indica, 2:1-241.

Kumar, A. and Takahashi, K. 1991. Palynology of the Tertiary sediments of southern Assam, India. Bulletin of Faculty of Liberal Arts, Nagasaki University (Natural Science), 31(2):515-659.

Lehmann, E.P. 1964. Tertiary-Cretaceous boundary facies in the Sirt Basin. Proceedings of 22nd International Geolological Congress, New Delhi, 3:56-73.

Mantell, G.A.1854. The Medals of Creation; or, First lessons in Geology, and the Study of Organic Remain. 2 volumes. $2^{\text {nd }}$ edition R. Clay, London.

Matsuoka, K., McMinn, A., and, Wrenn, J.H. 1997. Restudy of the holotype of Operculodinium centrocarpum (Deflandre and Cookson) wall (Dinophyceae) frm the Miocene of Australia, and the taxonomy of the related species. Palynology, 21:19-33.

Megerisi, M. and Mamgain, V.D. 1980. The Upper Cretaceous-Tertiary Formations of Northern Libya. In Salem, M.J. and Busrewil, M.T. (eds.), The Geology of Libya, 2nd Symposium on Geology of Libya, Tripoli. September 16-21, 1978.1(1):67-72.

Powell, A.J. 1992. Dinioflagellate cysts of the Tertiary System, p. 155-252, In Powell, A.J. (ed.), A Stratigraphic Index of Dinoflagellate Cysts.

Salem, M.J., Busrewil, M.T., Missalati, A.A., and, Sola, M.A.1996c. The Geology of Sirt Basin. Earth Science Society of Libya, 3. Elsevier.

Salem, M.J., El-Hawat, A.S., and, Sberta, A.M. 1996b. The Geology of Sirt Basin. Earth Science Society of Libya, 2. Elsevier. 
Salem, M.J., Mouzughi, A.J., and, Hammuda, O.S. 1996a. The Geology of Sirt Basin. Earth Science Society of Libya, 1. Elsevier.

Sarjeant, W.A.S. 1981. A restudy of some dinoflagellate cyst holotypes in the University of Kiel collections. II. The Eocene holotypes of Barbara Klumpp (1953); with revision of the genus Cordosphaeridium Eisenack, 1963. Meyniana, 33:97-132.

Saxena, R.K. and Trivedi, G.K. 2006. A Catalogue of Tertiary Spores and Pollen from India (1989-2004). Diamond Jubilee Publication, Birbal Sahni Institute of Palaeobotany, Lucknow, India.

Saxena, R.K. and Tripathi, S.K.M. 2012. Seven decades of Indian Tertiary spore-pollen flora: A compendium. American Association of Stratigraphic Palynologists, Contribution Series 45.

Sinha, R.N. and Mriheel, I.Y. 1996. Evolution of subsurface Paleocene sequence and shoal carbonates, south central Sirt Basin, p 153-195. In Salem, M.J., El-Hawat, A.S. and Sbeta, A.M. (eds.), The Geology of Sirt Basin 2, Tripoli, Libya.

Stead, D.T. 2007. Cenozoic palynofloras from northeast Libya, p. 183-233. In Keegan, J. B and Mansouri, A.L. (eds.), Subsurface Biostratigraphy of the Cretaceous to Cenozoic of Northeast Libya. Wellstrat Services Limited, U.K.

Stover, L.E. 1977. Oligocene and Early Miocene dinflagellates from Atlantic Corehole 5/5B, Blake Plateau. American Association of Stratigraphic Palynologists, Contribution Series no. 5A: 66-89.

Stover, L.E. and Evitt, W.R. 1978. Analyses of pre-Pleistocene organic-walled dinoflagellates. Stanford University Publications, Geological Sciences, 15. Stanford, CA.

Tmalla, A.F.A. 1992. Stratigraphic position of the Cretaceous-Tertiary boundary in the northern Sirt Basin, Libya. Marine and Petroleum Geology, 9:542-552.

Tmalla, A.F.A. 1996. Latest Maastrichtian and Paleocene planktonic foraminiferal biostratigraphy of well A1a NC29A, northern Sirt Basin, p. 195-232. In Salem, M.J., Mouzughi, A.J., and Hammuda, O.S. (eds.), The Geology of Sirt Basin, 1, Elsevier. van der Hammen, T. 1956. Description of some genera and species of fossil pollen and spores. Boletin Geologia Bgota, 2 (2-3):114-117.

van Hoeken-Klinkenberg, P.M.J. 1966. Maastrichtian, Paleocene and Eocene pollen and spores from Nigeria. Pollen et Spores, 6:209-231.

Venkatachala, B.S. 1973. Palynological evidence on the age of Cuddalore Sandstone. Geophytology, 3(2):145-149.

Venkatachala, B.S. and Rawat, M.S. 1972. Palynology of the Tertiary sediments in the Cauvery Basin-1. Palaeocene-Eocene palynoflora from the subsurface. p. 292-335. In Ghosh A.K., Chanda, S., Ghosh, T.K., Baksi, S.K., and Banerjee, M. (eds.), Proceedings of the Seminar on Paleopalynology and Indian Stratigraphy, Calcutta, 1971. Botany Department, Calcutta University.

Wennekers, J.H.N., Wallace, F.K., and, Abugares, Y.I. 1996. The geology and hydrocarbons of the Sirt Basin: A synopsis, p. 3-56. In Salem, M.J., Mouzughi, A.J., and O.S. Hammuda, O.S. (eds.), The Geology of Sirt Basin, 1. Elsevier.

Williams, G.L. 1978. Palynological biostratigraphy, Deep Sea drilling Sites 367 and 370, p. 783-815. In Lancelot, Y. et al. (eds.), Deep Sea Drilling Project, Initial Reports 41. Washington, D. C.

Williams, G. L. and Bujak, J. P. 1985. Mesozoic and Cenozoic dinoflagellates, p. 847-995. In Bolli, H. M., Saunders, J. B. and Perch-Nielsen, K. (eds.). Plankton Stratigraphy, 2. Cambridge Earth Science Series, Cambridge University Press.

Williams, G.L. and Downie, C. 1966. Further dinoflagellate cysts from the London Clay. In Davey, R.J., Downie, C., Sarjeant, W.A.S., and Williams, G.L. (eds.), Studies on Mesozoic and Cenozoic dinoflagellate cysts. British Museum (Natural History) Geology, Bulletin Supplement 3, London.

Williams, G.L., Stover, L.E., and Kidson, E.J. 1993. Morphologic and stratigraphic ranges of selected Mesozoic-Cenozoic dinoflagellate taxa in the northern hemisphere. Geological Survey of Canada Paper, 92-10:1-137. 